Geosistemy perehodnykh zon = Geosystems of Transition Zones / Геосистемы переходных зон

Content is available under the Creative Commons Attribution 4.0 International License (CC BY 4.0)

2021, vol. 5, No. 3, pp. 240-254

URL: http://journal.imgg.ru/archive.html ; https://elibrary.ru/title about.asp?id=64191

https://doi.org/10.30730/gtrz.2021.5.3.240-247.247-254

\title{
Distribution of methane fluxes on the water-atmosphere interface in different regions of the World Ocean
}

Galina I. Mishukova, https://orcid.org/0000-0003-1820-6069, gmishukova@poi.dvo.ru

Andrey V. Yatsuk, https://orcid.org/0000-0003-3975-5438, yatsuk@poi.dvo.ru

Renat B. Shakirov, https://orcid.org/0000-0003-1202-0351, ren@poi.dvo.ru

V.I. Il'ichev Pacific Oceanological Institute, Far Eastern Branch, Russian Academy of Science, Vladivostok, Russia

\section{Abstract PDF ENG Резюме PDF RUS $\quad$ Full text PDF RUS \& ENG}

Abstract. For the first time, methane fluxes at the water-atmosphere interface were calculated for the water area of Pacific, Indian, and Atlantic oceans (for the area about 30,000 miles) on the basis of the expeditionary measurements of methane concentrations in the surface layer of water and subsurface layer of the atmosphere along the entire course of the vessel. Methane fluxes at the water-atmosphere interface were calculated for the water areas of the Pacific, Indian and Atlantic oceans. In the result of the studies carried out in various regions of the World Ocean, an uneven spatial distribution of methane fluxes from strong absorption to emission of anomalous intensity was observed. The article presents the results of a detailed study for the deep-water area of the Indian Ocean open waters in the northern part of the Ninetyeast Ridge. Both supersaturation and undersaturation of seawater respectively to its concentrations in the atmosphere have been revealed on the basis of the direct measurements of methane concentrations in the ocean surface water layer. The distribution of dissolved methane in the water column of the Indian Ocean has been considered.

\section{Keywords:}

\section{methane flux, distribution, methane concentration, Indian Ocean}

For citation: Mishukova G.I., Yatsuk A.V., Shakirov R.B. Distribution of methane fluxes on the water-atmosphere interface in different regions of the World Ocean. Geosistemy perehodnykh zon = Geosystems of Transition Zones, 2021, vol. 5, no. 3, pp. 240-254. (In Russ. \& Engl.). https://doi.org/10.30730/gtrz.2021.5.3.240-247.247-254

Для цитирования: Мишукова Г.И., Яцук А.В., Шакиров Р.Б. Распределение потоков метана на границе вода-атмосфера в различных районах Мирового океана. Геосистемы переходных зон, 2021, т. 5, № 3, с. 240-254. (На рус. и англ.). https://doi.org/10.30730/gtrz.2021.5.3.240-247.247-254

\section{References}

1. Bange H.W., Bartell U.H., Rapsomanikis S., Andrae M.O. 1994. Methane in the Baltic and the North Seas and reassessment of marine emissions of methane. Global Biogeochem. Cycles, 8(4): 465-480. https://doi.org/10.1029/94gb02181

2. Berner U., Poggenburg J., Faber E., Quadfasel D., Frische A. 2003. Methane in ocean waters of the Bay of Bengal: its sources and exchange with the atmosphere. Deep Sea Research. Pt II: Topical Studies in Oceanography, 50(5): 925-950. https://doi.org/10.1016/s0967-0645(02)00613-6

3. Boetius A., Ferdelman T., Lochte K. 2000. Bacterial activity in sediments of the deep Arabian Sea in relation to vertical flux. Deep-Sea Research. Pt II: Topical Studies in Oceanography, 47(14): 2835-2875. https://doi.org/10.1016/s0967$\underline{0645(00) 00051-5}$

4. Bohrmann G., Chin C., Petersen S. et al. 1998. Hydrothermal activity at Hook Ridge in the Central Bransfield Basin, Antarctica. Geo-Marine Letters, 18: 277-284. https://doi.org/10.1007/s003670050080

5. Callender W.R., Powell E.N. 1999. Why did ancient chemosynthetic seep and vent assemblages occurs in shallower water than they today? International J. of Earth Sciences, 88: 377-391. https://doi.org/10.1007/s005310050273

6. Cicerone R.J., Oremland R. 1988. Biogeochemical aspects of atmospheric methane. Global Biogeochemical Cycles, 2(4): 299-327. https://doi.org/10.1029/gb002i004p00299

7. Conrad R., Seiler W. 1988. Methane and hydrogen in seawater (Atlantic Ocean). Deep Sea Research. Pt A. Oceanographic Research Papers, 35: 1903-1917. https://doi.org/10.1016/0198-0149(88)90116-1

8. Dickens G.R. 2001. Modeling the global carbon cycle with a gas hydrate capacitor: significance for the latest Paleocene thermal maximum. In: C.K. Paull., W.P. Dillon (eds). Natural Gas Hydrates: Occurrence, Distribution, and Dynamics, $19-38$. (American Geophysical Union. Geophysical Monograph Series; 124). https://doi.org/10.1029/GM124p0019

9. Ehhalt D.H. 1974. The atmospheric cycle of methane. Tellus, 26(84): 58-70. https://doi.org/10.3402/tellusa.v26i1-2.9737

10. Fischer D., Mogollón J., Strasser M. et al. 2013. Subduction zone earthquake as potential trigger of submarine hydrocarbon seepage. Nature Geoscience, 6: 647-651. https://doi.org/10.1038/ngeo1886

11. Geologicheskoe stroenie i gidrotermal'nye obrazovaniya khrebta Khuan-de-Fuka [Geological structure and hydrothermal deposits of the Juan de Fuca Ridge] (ed. A.P. Lisitsyn). 1990. Moscow: Nauka, 199 p. (In Russ.). 
12. Ginsburg G.D., Solov'ev V.A. 1994. Submarinnye gazovye gidraty [Submarine gas hydrates]. Leningrad: VNIIOkeangeologiya, 86 p. (In Russ.).

13. Goryainov N.I., Gramberg I.S., Smekalov A.S. et al. 2000. [On a possible dependence of global growth of methane concentration in the troposphere on the number of week earthquakes]. Geologiya i geofizika, 41(8): 1187-1194. (In Russ.).

14. Kirschke S., Bousquet Ph. ... Zeng G. 2013. Three decades of global methane sources and sinks. Nature Geoscience, 6: 813-823. https://doi.org/10.1038/ngeo1955

15. Kopf A.J. 2002. Significance of mud volcanism. Reviews of Geophysics, 40(2): 1005. https://doi.org/10.1029/2000rg000093

16. Kvenvolden K.A. 1988. Methane hydrate - a major reservoir of carbon in the shallow geosphere. Chemical Geology, 71 : 41-51. https://doi.org/10.1016/0009-2541(88)90104-0

17. Kvenvolden K.A., Kastner M. 1990. Gas hydrates of the Peruvian outer continental margin. In: Suess E., von Huene R. et al. (eds). Proceedings of the Ocean Drilling Program: Scientific results, 112: 517-526. https://doi.org/10.2973/odp.proc.sr.112.147.1990

18. Legkodimov A.A., Mishukova O.V., Shvalov D.A., Makseev D.S., Shakirova M.V., Bakunina M.S., Es'kova E.I. 2019. Discussion on methane emission from the water area of the tatar strait, the Sea of Japan (basing on the 55-th Cruise of RV "Akademik Oparin"). Vestnik DVO RAN = Vestnik of the Far East Branch of the Russian Academy of Sciences, 2: 81-87. (In Russ.). doi:10.25808/08697698.2019.204.2.009

19. Lein A.Yu., Sagalevich A.M. 2000. [Smokers of the Rainbow field - the area of large-scale abiogenic methane synthesis]. Priroda, 8: 44-53. (In Russ.).

20. Levchenko O.V., Sborshchikov I.M., Marinova Yu.G. 2014. Tectonics of the Ninety-East Ridge. Oceanology, 54(2): 231244. https://doi.org/10.1134/s0001437014020143

21. Levchenko O.V., Ananiev R.A., Veklich I.A, Ivanenko A.N., Marinova Yu.G., Turko N.N. 2018. Complex investigation of the seamount at the bottom of the northern part of the Ninety East Ridge. Vestnik KRAUNTs. Nauki o Zemle = Bull. of Kamchatka Regional Association «Educational-Scientific Center». Earth Sciences, 3(39): 90-104. (In Russ.). https://doi.org/10.31431/1816-5524-2018-3-39-90-104

22. Long D., Lammers S., Linke P. 1998. Possible hydrate mounds within large sea-floor craters in the Barents Sea. Geological Society, London, Spec. Publ., 137: 223-237. doi:10.1144/GSL.SP.1998.137.01.18

23. Max M.D., Dillon W.P., Nishimura C., Hurdle B.G. 1999. Sea floor methane blow-out and global firestorm at the K+T boundary. Geo-Marine Letters, 18: 285-291. https://doi.org/10.1007/s003670050081

24. Mienert J., Posewang J. 1999. Evidence of shallow- and deep-water gas hydrate destabilizations in North Atlantic polar continental margin sediments. Geo-Marine Letters, 19: 143-149. https://doi.org/10.1007/s003670050101

25. Mischoukov V., Mishukova G. 1999. White caps and bubble mechanisms of gas exchange between ocean and atmosphere. In: Y. Nojiri (ed.). Proceedings of the 2nd International Symp. " $\mathrm{CO}_{2}$ in the Oceans". Environ. Agency of Japan, 517-520.

26. Mishukova G.I., Shakirov R.B. 2017. Spatial variations of methane distribution in marine environment and its fluxes at the water-atmosphere interface in the western Sea of Okhotsk. Water Resources, 44(4): 662-672. https://doi.org/10.1134/s0097807817040133

27. Mishukova G.I., Obzhirov A.I., Mishukov V.F. 2007. [Methane contents in fresh and sea waters and it's fluxes on border of water-atmosphere at Far Eastern Region of Asia]. Vladivostok: Dal'nauka, 159 p. (In Russ.).

28. Mishukova G.I., Pestrikova N.L., Mishukov V.F., Yanovskaya O.S. 2011. Distribution of methane and calculation of its fluxes on the boundary of the seawater-atmosphere in the northwestern part of the Sea of Japan in warm season. Podvodnye issledovaniya i robototekhnika = Underwater Investigations and Robotics, 1(11): 68-74. (In Russ.).

29. Mishukova G.I., Pestrikova N.L., Vereschagina O.F., Okulov A.K., Mishukov V.F. 2013. Space and temporal change of methane distribution and it's fluxes on the border of water-atmosphere in the seawater area nearby Kurile Islands in the Sea of Okhotsk and in the Pacific Ocean. Podvodnye issledovaniya i robototekhnika = Underwater Investigations and Robotics, 1(15): 52-61. (In Russ.).

30. Mishukova G.I., Mishukov V.F., Obzhirov A.I., Pestrikova N.L., Vereshchagina O.F. 2015. Peculiarities of the distribution of methane concentration and methane fluxes at the water-air interface in the Tatar Strait of the Sea of Japan. Russian Meteorology and Hydrology, 40(6): 427-433. doi:10.3103/S1068373915060096

31. Mishukova G.I., Shakirov R.B., Obzhirov A.I. 2017. Methane fluxes on the water-atmosphere boundary in the Sea of Okhotsk. Doklady Earth Sciences, 475(2): 963-967. https://doi.org/10.1134/s1028334x17080256

32. Mishukova O., Shakirov R., Yatsuk A. 2019. Methane fluxes on the water-atmosphere interface in the north-west of the Sea of Japan during spring-summer-autumn (2010-2018). In: Marine Science and Technology for Sustainable Development: Abstracts of the 26th Intern. Conf. of Pacific Congress on Marine Science and Technology (PACON-2019), July 16-19, 2019, Vladivostok, Russia. Vladivostok: POI FEB RAS, p. 84.

33. Obzhirov A.I., Pestrikova N.L., Mishukova G.I., Mishukov V.F., Okulov A.K. 2016. Distribution of methane content and methane fluxes in the Sea of Japan, Sea of Okhotsk, and Near-Kuril Pacific. Russian Meteorology and Hydrology, 41(3): 205-212. doi:10.3103/S1068373916030067

34. Obzhirov A.I., Mishukova G.I., Shakirov R.B., Mishukov V.F., Maltseva E.V., Sokolova N.L., Okulov A.K., Yatsuk A.V., Lifanskiy E.V. 2020(2019). Interseasonal variability in methane concentrations and fluxes at the water-atmosphere boundary in the western Sea of Okhotsk. Oceanology, 59(6): 853-859. https://doi.org/10.31857/s0030-1574596944-951

35. Paull C.K., Brewer P.G., Ussler W., Peltzer E.T., Rehder G., Clague D. 2003. An experiment demonstrating that marine slumping is a mechanism to transfer methane from seafloor gas-hydrate deposits into the upper ocean and atmosphere. Geo-Marine Letters, 22: 198-203. https://doi.org/10.1007/s00367-002-0113-y

36. Reeburgh W.S. 2007. Oceanic methane biogeochemistry. Chemical Reviews, 107: 486-513. https://doi.org/10.1021/cr050362v

37. Sarano F., Murphy R.C., Houghton B.F., Hedenquist J.W. 1989. Preliminary observations of submarine geothermal activity in the vicinity of the White Island Volcano, Taupo volcanic zone, New Zeland. J. of the Royal Society of New Zealand, 19 (4): 449-459. https://doi.org/10.1080/03036758.1989.10421847

38. Saunois M., Bousquet Ph., Poulter B., Peregon A., Ciais Ph., Canadell J.G., Dlugokencky E.J., Etiope G., Bastviken D., Houweling S. et al. 2016. The global methane budget 2000-2012. Earth System Science Data, 8: 697-751. doi:10.5194/essd-8-697-2016

39. Schubert C.J., Nurnberg D., Scheele N., Pauer F., Kriews M. 1997. ${ }^{13} \mathrm{C}$ isotope depletion in ikaite crystals: evidence for methane release from the Siberian shelves? Geo-Marine Letters, 17: 169-174. https://doi.org/10.1007/s003670050023 
40. Shakirov R.B., Mishukova O.V. 2019. The spatial distribution of the methane fluxes on the water-atmosphere boundary in the Sea of Okhotsk. Geosistemy perehodnykh zon = Geosystems of Transition Zones, 3(1): 107-123. (In Russ.). doi.org/10.30730/2541-8912.2019.3.1.107-123

41. Shakirov R.B., Yatsuk A.V., Mishukova G.I., Obzhirov A.I., Yugai I.G., Legkodimov A.A., Shakirova M.V., Cuong D.H., Lan N.H. 2019a. Methane flux into the atmosphere in the South China Sea. Doklady Earth Sciences, 486(1): 533-536. https://doi.org/10.1134/s1028334x19050064

42. Shakirov R.B., Valitov M.G., Obzhirov A.I., Mishukov V.F., Yatsuk A.V., Syrbu N.S., Mishukova O.V. 2019b. Methane anomalies, its flux on the sea-atmosphere interface and their relations to the geological structure of the South-Tatar sedimentary basin (Tatar Strait, the Sea of Japan). Marine Geophysical Research, 40: 581-600. https://doi.org/10.1007/s11001-019-09389-3

43. Shakirov R.B., Valitov M.G., Syrbu N.S., Yatsuk A.V., Obzhirov A.I., Mishukov V.F., Lifanskii E.V., Mishukova O.V., Salomatin A.S. 2020. Methane fluxes at the water-atmosphere interface in the southern Tatar Strait of the Sea of Japan: distribution and variation. Russian Geology and Geophysics, 61(9): 994-1006. https://doi.org/10.15372/rgg2019184

44. Suess E., Torres M.E., Bohrmann G., Collier R.W., Greinert J., Linke P., Rehder G., Trehu A., Wallmann K., Winckler G., Zuleger E. 1999. Gas hydrate destabilization: enhanced dewatering, benthic material turnover and large methane plumes at the Cascadia convergent margin. Earth and Planetary Science Letters, 170 (1-2): 1-15. https://doi.org/10.1016/s0012$821 \times(99) 00092-8$

45. Trehu A.M., Torres M.E., Moore G.F., Suess E., Bohrmann G. 1999. Temporal and spatial evolution of a gas hydratebearing accretionary ridge on the Oregon continental margin. Geology, 27(10): 939-942. https://doi.org/10.1130/00917613(1999)027<0939:taseoa>2.3.c0;2

46. Vereshchagina O.F., Korovitskaya E.V., Mishukova G.I. 2013. Methane in water columns and sediment of north wester Sea of Japan. Deep Sea Research. Pt II: Topical studies in Oceanography, 86-87: 25-33. https://doi.org/10.1016/i.dsr2.2012.08.017

47. Weber Th., Wiseman N.A., Kock A. 2019. Global ocean methane emissions dominated by shallow coastal waters. Nature Communications, 10: 4584. https://doi.org/10.1038/s41467-019-12541-7

48. Wiesenburg D.A., Guinasso N.L. 1979. Equilibrium solubility of methane, carbon monooxide, and hydrogen in water and seawater. J. of Chemical \& Engineering Data, 24(4): 356-360. https://doi.org/10.1021/je60083a006

49. Yamamoto S., Alcauskas J.B., Crozier T.E. 1976. Solubility of methane in distilled water and seawater. J. of Chemical \& Engineering Data, 21(1): 78-80. https://doi.org/10.1021/je60068a029

50. Zubova M.A. 1988. Gidraty prirodnykh gazov $v$ nedrakh Mirovogo okeana [Natural gas hydrates in the World Ocean subsoil. Moscow: VIEMS, 61 p. (In Russ.). 